\title{
IGF-I induces DNA synthesis and apoptosis in rat liver hepatic stellate cells (HSC) but DNA synthesis and proliferation in rat liver myofibroblasts (rMF)
}

\author{
Bernhard Saile, Paola DiRocco, Joszef Dudas, Hammudeh El-Armouche, Holger Sebb, \\ Christoph Eisenbach, Katrin Neubauer and Giuliano Ramadori \\ Department of Internal Medicine, Section of Gastroenterology and Endocrinology, University of Göttingen, \\ Göttingen, Germany
}

\begin{abstract}
Several lines of evidence suggest a role of insulin-like growth factor I (IGF-I) in the regulation of apoptosis. Up to now its impact on many specific cells is unknown. We therefore studied the effect of IGF-I on two similar mesenchymal matrix-producing cell types of the liver, the hepatic stellate cells (HSC) and the myofibroblasts (rMF). The present study aimed to reveal the influence of IGF-I on cell cycle and apoptosis of HSC and rMF and to elucidate responsible signaling. While IGF-I significantly increased DNA synthesis in HSC, cell number decreased and apoptosis increased. In rMF IGF-I also increased DNA synthesis, which is, however, followed by proliferation. Blocking extracellular signal regulating kinase (ERK) revealed that in $\mathrm{HSC}$, bcl-2 upregulation and bax downregulation are effected downstream of ERK, whereas downregulation of NFkB and consecutive of bcl$x_{L}$ is mediated upstream. In the rMF upregulation of both, the antiapoptotic bcl-2 and bcl- $x_{L}$ is mediated upstream of ERK. The expression of the proapoptotic bax is not regulated by IGF-I in rMF. The studies demonstrate a completely different effect and signaling of IGF-I in two morphologically and functionally similar matrix-producing cells of the liver.
\end{abstract}

Laboratory Investigation (2004) 84, 1037-1049, advance online publication, 24 May 2004; doi:10.1038/labinvest.3700116

Keywords: hepatic stellate cells; liver myofibroblasts; IGF-I; apoptosis; proliferation; cell-cycle; ERK

Insulin-like growth factor I (IGF-I) is involved in various metabolic, proliferative and differentiation processes. After acute liver damage, hepatocytes have been shown to secrete IGF-I in the preinflammatory step. In the inflammatory step of liver fibrogenesis, Kupffer cells and activated hepatic stellate cells (HSC) have been shown to secrete IGFI, suggesting a great importance of IGF-I during liver fibrogenesis (for a review, see Gressner). ${ }^{1}$ Above that in adult rats the liver is considered as the main source of circulating IGFs. ${ }^{2-4}$

The biological effects of IGF-I are mediated via activation of its IGF-I receptor (IGF-I R), which is a member of the tyrosine kinase growth factor receptor family. Binding of IGF-I induces a conformational

Correspondence: Professor Dr G Ramadori, Department of Internal Medicine, Section of Gastroenterology and Endocrinology, Georg-August-University Göttingen, Robert-Koch-Straße 40, 37075 Göttingen, Germany.

E-mail: gramado@med.uni-goettingen.de

Received 14 November 2003; revised 29 March 2004; accepted 30 March 2004; published online 24 May 2004 change of the receptor leading to autophosphorylation of several critical tyrosine residues that serve as docking sites for cytoplasmatic proteins containing SH2 (src homology 2) domains. In contrast to other receptor tyrosine kinases, the IGF-I R interacts with intermediate signaling proteins, for example, the insulin receptor substrate (IRS-I) and Src homology containing protein (Shc). ${ }^{5}$ IRS-I can be regarded as a multicomponent docking platform, binding multiple SH2 domain containing proteins and adaptor proteins, for example Grb2 ${ }^{6}{ }^{6} \mathrm{Nck},{ }^{7} \mathrm{C}-\mathrm{Crk},{ }^{8}$ the protein tyrosine phosphatase SH-PTP2 (Syp) ${ }^{9}$ and the p85 subunit of the phophatidylinositol 3-kinase (PI 3-K). ${ }^{10}$ All of them contain SH2 domains.

Studies on the intracellular signaling of IGF-I revealed two primary pathways by which IGF-I signals are transmitted, namely the PI $3-\mathrm{K}$ pathway and the extracellular signal-regulated kinase (ERK) pathways. These pathways are shown to interact at different levels in the mediation of the IGF-I response, whether mitogenic, antiapoptotic, differentiating or chemotactic. ${ }^{11-15}$ 
The 'activation' of hepatic stellate cells (so called since the consensus letter of $1996^{16}$ ), also known as Ito cells, lipocytes, vitamin A storing cells, perisinusoidal cells, liver pericytes, is considered to be an important step in liver tissue repair as well as in the development of liver fibrosis. The term activation describes the transformation of the Vitamin A storing 'quiescent' cell to a myofibroblast-like 'activated' HSC. Both the 'activated' HSC (myofibroblast-like cells) along with the sinusoids and the morphologically similar liver myofibroblasts of the periportal and perivenous areas are shown to produce large amounts of extracellular matrix proteins, thus being responsible for extracellular matrix accumulation during chronic liver damage (for a review, see Cassiman and Roskams ${ }^{17}$ and Ramadori and Saile ${ }^{18}$ ).

With regard to their life characteristics the rat liver myofibroblasts (rMF) differ from activated HSC in vitro in the lack of occurrence of spontaneous apoptosis due to different CD95L expressions, in their stronger susceptibility to CD95-mediated apoptosis as well as their reaction on TNF- $\alpha$ stimulation. ${ }^{19}$ Concerning the different behavior in culture and the importance of IGF-I during liver repair processes, in this paper we investigated the effect of IGF-I on HSC and rMF with respect to apoptosis, proliferation and IGF-I signaling. In HSC (quiescent as well as activated), IGF-I acts proapoptotic and antiproliferative in spite of inducing DNA synthesis. Both $\mathrm{NF} \kappa \mathrm{B}$ and ERK1/2 are involved in the proapoptotic effect of differentially regulating members of the bcl family, whereas the effect on DNA synthesis is restricted to the ERK $1 / 2$ pathway. In rMF, IGF-I acts antiapoptotic via the bcl system acting upstream of ERK1/2. However, ERK1/2 is needed for proliferation stimulation. The $\mathrm{NF} \kappa \mathrm{B} / \mathrm{I} \kappa \mathrm{B}$ system is not involved in the IGF-I signal transduction pathway in rMF.

\section{Material and methods}

\section{Animals}

Wistar rats were provided by Charles River (Sulzfeld, Germany) and maintained under $12 \mathrm{~h}$ light/ dark cycles with food and water ad libitum. All animals received humane care in accordance to institution's and the National Institutes of Health guidelines.

\section{HSC and rMF Isolation, Plating and Culture Conditions}

HSC were isolated by sequential in situ perfusion with collagenase and pronase as described previously. ${ }^{20}$ Yields of $40 \times 10^{6}$ HSC in mean were obtained per rat. Purity was $>85 \%$ in freshly isolated cells. Cells were plated with a density of
30000 cells $/ \mathrm{cm}^{2}$ and cultured in Dulbecco's modified Eagle's medium (DMEM) supplemented with $15 \%$ fetal calf serum (FCS), $100 \mathrm{U} / \mathrm{ml}$ penicillin, $100 \mu \mathrm{g} / \mathrm{ml}$ streptomycin and $1 \%$ L-glutamine. Culture medium was replaced at 2 days after plating and then every other day. Cells were kept in culture at $37^{\circ} \mathrm{C}$ in a $5 \% \quad \mathrm{CO}_{2}$ atmosphere and $100 \%$ humidity.

For isolation of rMF, the liver was enzymatically digested as described above. The nonparenchymal liver cell population was separated by a Nycodenz density gradient and the fraction also containing Kupffer cells and sinusoidal endothelial cells was further purified by centrifugal elutriation according to Knook et $a l^{21}$ and De Leeuw et $a l^{22,23}$ Using a JE$6 \mathrm{~B}$ elutriation rotor in a J2-21 centrifuge (Beckman Instruments, Palo Altro, CA, USA) at $2500 \mathrm{rpm}$, a fraction enriched with $\mathrm{MMF}$ was collected at a flow rate of $23 \mathrm{ml} / \mathrm{min}^{19}$ (At a flow rate of $19 \mathrm{ml} / \mathrm{min}$ endothelial cells can be collected while Kupffer cells can be extracted at a flow rate of $55 \mathrm{ml} / \mathrm{min}$ using the same procedure). A measure of $60 \times 10^{6}$ rMF was obtained in mean per rat. Cells were plated at a density of 30000 cells $/ \mathrm{cm}^{2}$ and cultured under the same conditions like HSC (see above). At confluency, usually reached within 7-10days, cells were released from the culture plates by trypsination and were replated at a 1:4 split ratio. rMF were passaged again at confluency using the same experimental condition.

\section{Characterization of HSC and rMF and Purity of Isolation}

The purity of HSC cultures was tested by immunocytology at day 0 , day 2 (quiescent HSC/'early activated' HSC) and day 7 (activated HSC) as described. ${ }^{19}$ In freshly isolated cells as well as at day 2 of culture, myofibroblasts as assessed by smooth muscle $\alpha$ actin (SMA)-positive, Fibulin-2positive and reelin-negative cells were always $<1 \% .{ }^{24,25}$ Contamination with Kupffer cells (ED1 positive) was $<2 \%$ and neither endothelial cells nor hepatocytes were detected. Using SMA immunoreactivity as an activation parameter, HSC were fully activated after 7 days of primary culture $(100 \%$ SMA positive).

The purity of freshly isolated rMF as assessed by fibulin-2 positivity, SMA positivity and reelin negativity was $98 \% .{ }^{19}$ HSC containing the typical fat droplets could not be detected by lightmicroscopy. However, the presence of so-called 'empty' HSC not containing typical vacuoles cannot totally be excluded. However, as empty HSC at least should be positive for one of the marker proteins like desmin, GFAP or V-CAM-1 that were undetectable (GFAP), or present in less than $1.5 \%$ (desmin) or $0.5 \%$ (V-CAM-1) of the isolated cells, a considerable contamination of the $23 \mathrm{ml} / \mathrm{min}$ fraction with 'empty' HSC is unlikely. 


\section{Culture Conditions for Stimulation with IGF-I}

HSC at days 2 and 7 of primary culture and rMF (primary culture and passages 2) were washed three times with Gey's balanced salt solution and incubated for $20 \mathrm{~h}$ in serum-reduced $0.3 \%$ fetal calf serum) culture medium alone or in the presence of IGF-I $\left(10^{-11} \mathrm{M}, 10^{-9} \mathrm{M}, 10^{-7} \mathrm{M}, 10^{-5} \mathrm{M}\right.$ ) (Sigma, Deisenhofen, Germany). The optimal concentrations and incubation time of the cytokines used have previously been tested and shown to have no cytotoxic effects.

Inhibition of IGF-1 Receptor Activity by Tyrphostin AG1024 or ERK1/2 Activity by Tyrphostin AG99 or U0126

For investigation of IGF-1 receptor activity as well as ERK1/2 activity, we used tyrphostin AG1024 (3bromo-5-t-butyl-4-hydroxy-benzylidenemalonitrile; Calbiochem, Frankfurt, Germany), tyrphostin AG99 (=tyrphostin A46; $\alpha$-cyano-(3,4-dihydroxy)cinnamide) or U0126 (Alexis, Grünberg, Germany). As internal control for tyrphostins, tyrphostin A1 ((4methoxybenylidene) malonitrile; $\alpha$-cyano-(4-methoxy)cinnamonitrile) was used, a structurally homologeous molecule, which does not exhibit biological activity. HSC at days 2 and 7 of primary culture and rMF (primary culture and passage 2) were washed three times with Gey's balanced salt solution and incubated for $20 \mathrm{~h}$ in serum-reduced $(0.3 \%$ fetal calf serum) culture medium alone or in the presence of tyrphostin AG1024 $(100 \mu \mathrm{M})$, tyrphostin AG99 $(50 \mu \mathrm{M})$ or tyrphostin A1 $(100 \mu \mathrm{M}$ respectively $50 \mathrm{nM}$ ) or U0126 (Promega, Mannheim, Germany) $(50 \mu \mathrm{M})$. Compared to serum-reduced cultures, no influence on apoptosis and DNA synthesis of HSC and rMF could be observed under the influence of tyrphostin A1.

\section{Flowcytometric and Fluorescence Microscopic Quantification of Living, Apoptotic and Necrotic HSC or rMF}

For quantification of apoptotic cells, we used flow cytometry after trypsination of HSC and rMF (Epics ML, Coulter, Kerfeld, Germany). To detect apoptotic changes, staining with Annexin V-FITC/propidiumiodide and the TUNEL method (Tdt-mediated XdUTP nick end labeling) (Boehringer, Mannheim, Germany) were used. Data obtained by TUNELlabeling were identical to those obtained with the Annexin V-FITC/propidiumiodide binding. As a third method to detect apoptosis on the single-cell level, we used the mitochondrial membrane sensor kit from Clontech, Palo Alto, California, USA. Briefly, the basis of this method is the fact that the dye is able to accumulate in intact mitochondria. In case of apoptosis it aggregates in the cytosol and alters the fluorescence color. By this change of the fluorescence color, it is possible to discriminate between apoptotic and living cells.

\section{Caspase-8, Caspase-9 and Caspase-3 Activity}

For detection of active caspase-8, caspase-9 and caspase-3, we used the Active Caspase Set of Pharmigen, Germany. Cell lysates of $5 \times 10^{6}$ cells were applied and active caspase-8, active caspase-3 or active caspase- 9 were detected according to the manufacturer's protocol. To evaluate substrate specifity, caspase-8, caspase-9 or caspase-3 inhibitors (Oncogene, MA, USA) were used.

\section{BrdU-Elisa for DNA Synthesis}

To measure DNA synthesis, we used a BrdU labeling and detection ELISA kit (Boehringer, Mannheim, Germany), quantitating BrdU incorporated into newly synthesized DNA of replicating cells. Cultures were incubated with BrdU for $20 \mathrm{~h}$, at $37^{\circ} \mathrm{C}$. BrdU uptake was measured according to the standard ELISA protocol. The data presented are normalized on cell number of cultures of the same isolate (alive + apoptotic cells), measured by flow cytometry and microscopic counting.

\section{BrdU-Incorporation and Apoptosis}

To follow the process of DNA synthesis and apoptosis, we used laser scan microscopy. Briefly, for immunolabeling, cells were preincubated with BrdU for $12 \mathrm{~h}$ prior to IGF-1 administration. At distinct time points (for HSC day 2: 4, 5, 6, 7, $8 \mathrm{~h}$; for HSC day 7 and rMF: 8, 9, 10, 11, 12 h), immunofluorescence was performed using an anti-BrdU antibody (Alexis, Grünberg, Germany) as a first antibody and a TRIC-labeled anti-mouse antibody as a second antibody. As negative controls, the first antibody was substituted by mouse IgG (Sigma, Deisenhofen, Germany). After that, the apoptosis was detected by the TUNEL method (Boehinger, Mannheim, Germany). As negative control, the TUNEL reaction mixture was used without terminal transferase. Maximum immunofluorescence of the negative controls was digitally removed. However, for better evaluation, the red channel (BrdU) was not completely suppressed to maximum fluorescence of the negative controls, so that all nuclei could be identified and counted. Colocalization of BrdU and TUNEL provided a yellow color.

\section{Cell-Cycle Analysis}

A measure of $5 \times 10^{5}$ cells in $200 \mu \mathrm{l} \mathrm{Ca}^{2+}$-, $\mathrm{Mg}^{2+}$-free PBS was fixed in $4 \mathrm{ml} 70 \%$ ethanol $/ 30 \% \mathrm{PBS}$ at $0^{\circ} \mathrm{C}$, digested with $1000 \mathrm{U}$ RNase A (Sigma) and stained with $1 \%$ propidiumiodide at $37^{\circ} \mathrm{C}$ for $30 \mathrm{~min} .{ }^{26}$ The DNA profiles were determined within $4 \mathrm{~h}$ of staining 
by flowcytometry (EPICS ML, Coulter, Krefeld, Germany). Data were analyzed using the program Multicycle for Windows Ver. 3.0 (Phoenix Flow Systems, CA, USA).

\section{Western Blot Analysis of IGF-I Receptor, CD95, CD95L, bcl-2, bcl- $\mathrm{x}_{\mathrm{L}}$, bax, p53, p21 ${ }^{\mathrm{WAF} 1}$, NF $\kappa \mathrm{B}^{\mathrm{p} 65}, \mathrm{I} \kappa \mathrm{B}$, Phosphorylated ERK1/2}

Cells at different times after plating were lysed in hot Laemmli buffer $\left(95^{\circ} \mathrm{C}\right)$ and processed by sodium dodecyl sulfate polyacrylamide gel electrophoresis (SDS-PAGE) under reducing conditions according to Laemmli. $^{27}$ The protein content of cellular lysates was calculated by the Coomassie Protein Assay (Pierce, Rockfort, IL, USA). Proteins were transferred onto Hybond- ECL nitrocellulose hybridization transfer membranes according to Towbin et al. ${ }^{28}$ Immunodetection was performed according to the ECL Western blotting protocol. After detection of a protein, the nitrocellulose filter was stripped and used for immunodetection of the next protein. Primary antibodies (Calbiochem, Frankfurt, Germany) and primary antibody against phosphorylated ERK1/2 (Promega, Mannheim, Germany) were used at $2.5 \mu \mathrm{g} / \mathrm{ml}$ solutions, and peroxidase-labeled antimouse and anti-rabbit immunoglobulins were each used at a 1/1000 dilution.

\section{Nuclear Extracts and Electromobility Shift Assay}

Nuclear extracts were prepared according to the method of Dignam et al. ${ }^{29}$ HSC $\left(5 \times 10^{6}\right)$ were harvested by scrape-harvesting into TBS $(20 \mathrm{mmol} / \mathrm{l}$ Tris, $\mathrm{pH} 7.2,0.15 \mathrm{~mol} / \mathrm{l} \mathrm{NaCl})$. The cells were resuspended in buffer A $(0.2 \mathrm{ml} ; 10 \mathrm{mmol} / \mathrm{l}$ HEPES, $\mathrm{pH}$ 7.9, $10 \mathrm{mmol} / \mathrm{l} \mathrm{KCl}, 1.5 \mathrm{mmol} / \mathrm{l} \mathrm{MgCl}_{2}$, leupeptin and aprotinin each $1 \mu \mathrm{g} / \mathrm{ml}$, PMSF $0.5 \mathrm{mmol} / \mathrm{l}$, $1 \mathrm{mmol} / \mathrm{l}$ orthovanadate, $2 \mathrm{mmol} / \mathrm{l}$ pyrophosphate) and incubated for $15 \mathrm{~min}$ on ice. After that $25 \mathrm{ml}$ $2.5 \% \mathrm{NP}-40 /$ buffer A was added, mixed by inversion and the nuclei were pelleted $\left(500 \mathrm{~g}, 4 \mathrm{~min}, 4^{\circ} \mathrm{C}\right.$ ). The nuclear proteins were extracted and analyzed as described previously. The antibodies specific for $\mathrm{NF} \kappa \mathrm{B}$ were purchased from Santa Cruz Biotech. The $\mathrm{NF} \kappa \mathrm{B}$ oligonucleotides (consensus binding site for $\mathrm{NF} \kappa \mathrm{B} / \mathrm{c}-\mathrm{Rel}$ ) and mutated oligonucleotides were purchased from Santa Cruz Biotechnology (Santa Cruz, CA, USA). To detect unspecific binding, competition experiments with a 10- to 100-fold excess of unlabeled specific oligonucleotides and mutated oligonucleotides with a ' $G$ ' $\rightarrow$ 'C' substitution in the $\mathrm{NF} \kappa \mathrm{B} / \mathrm{Rel}$ binding were performed. In all control experiments no unspecific binding was detected.

\section{Inhibition of ERK1/2 Translation by Antisense Technique}

In order to inhibit ERK1/2 translation, we used an antisense kit (Biognostics, Goettingen, Germany).
An FITC-labeled randomized sequence phosphorothioate oligonucleotide was used to monitor uptake efficiency. An uptake of the MAP kinase antisense oligonucleotide (Calbiochem, Frankfurt, Germany) or the control oligonucleotide (Calbiochem, Frankfurt, Germany) into $98 \%$ of the cells was achieved within $8 \mathrm{~h}$, as could be shown by immunofluorescence microscopy. Subsequently, IGF-1 was added to the HSC cultures for $20 \mathrm{~h}$. The occurrence of apoptosis and effect on cell cycle was measured using the methods described above. Prior studies never revealed an influence of the control oligonucleotide on apoptosis as well as on cell cycle in HSC and rMF.

\section{Statistical Analysis}

Results are expressed as mean \pm s.d., and the significance of the difference between the means was assessed by the Mann-Whitney $U$-test.

\section{Results}

\section{Influence of IGF-1 on Cell Cycle, Proliferation and Apoptosis in HSC and rMF}

After stimulation with IGF-I $\left(10^{-7} \mathrm{M}\right)$, cell-cycle analysis revealed a doubling of $\mathrm{S}$-phase portion in HSC day 7 (from 16.4 to $27.88 \%$; $P<0.05$ ), rMF day 7 (primary culture) (from 16.5 to $32.4 \% ; P<0.05$ ) and $\mathrm{rMF}$ passage 2 (from 18.3 to $30.8 \% ; P<0.05$ ). In quiescent HSC (day 2), S-phase cells were even fourfold $(16.4 \%)$ compared to the controls $(4.2 \%$; $P<0.05)$. Similar results were obtained using a BrdU-Elisa (data not shown). As expected, these data demonstrate again that IGF-I promotes cell cycle progression. On the other hand, great differences could be observed when taking a closer look at $\mathrm{G}_{0} / \mathrm{G}_{1^{-}}$and $\mathrm{G}_{2}$-phase. Whereas in quiescent and activated HSC (day 2; day 7) the greatest part of the cultures $(68.7 \%$ respectively $63.8 \%)$ are in the $\mathrm{G}_{2}$ phase after IGF-I stimulation, increment of S-phase portion in rMF (primary culture as well as passage 2) is at cost of $\mathrm{G}_{1}$-phase cells without any change of the $\mathrm{G}_{2}$-phase portion (14.6-19.6\%).

In order to evaluate the significance of these data, we additionally investigated the total cell number of the cultures using FACS analysis and direct cell counting. As first result we found that total cell number in HSC decreased by $22 \pm 1.4 \%$ from day 2 to day 7. Stimulation with IGF-I $\left(10^{-7} \mathrm{M}\right)$ additionally led to a decrease of cell number in quiescent HSC (day 2) by $40 \%(P<0.01)$ and in activated HSC (day 7$)$ by $20 \%(P<0.05)$. In contrast, in rMF cultures IGF-I administration resulted in an increment of cell number by $62-70 \% \quad(P<0.05)$ indicating real proliferation.

IGF-I administration effected an increment of apoptosis in HSC cultures in a dose-dependent manner. This effect is particularly evident in quiescent HSC (day 2) and also significant in 


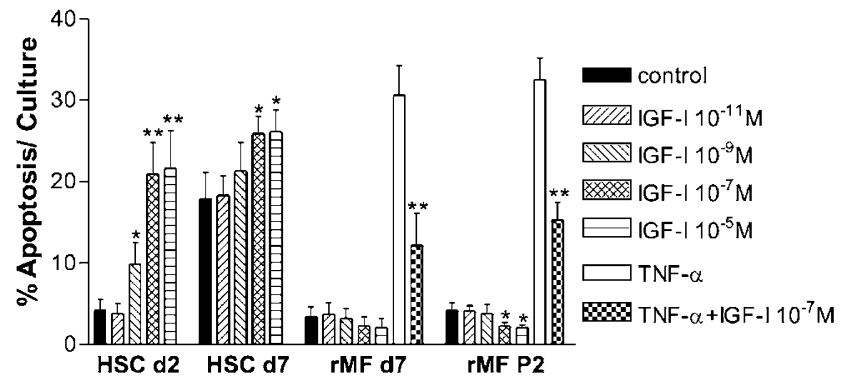

Figure 1 Influence of IGF-I on apoptosis of HSC and rMF. Flowcytometric quantification of apoptosis of resting HSC (day 2), activated HSC (day 7), rMF (primary culture day 7) and rMF (passage 2) under serum-reduced conditions (0.3\% FCS; $20 \mathrm{~h})$ incubated with IGF-I. For demonstrating an antiapoptotic effect of IGF-I on rMF, cultures were additionally stimulated with TNF- $\alpha$ $(100 \mathrm{U} / \mathrm{ml})$, which has previously been shown to induce apoptosis in rMF. The data show the percentage portion of apoptotic cells per total population using the Annexin V/propidiumiodidemethod. Values presented are means \pm s.d. of seven different isolations. Level of significance: ${ }^{*} P<0.05 ;{ }^{*} P<0.01$.

activated HSC (day 7). Concentrations exceeding $10^{-7} \mathrm{M}$ have no further apoptosis-stimulating effect. In rMF cultures that per se show a low amount of spontaneous apoptosis, IGF-1 concentrations of $10^{-7} \mathrm{M}$ and $10^{-5} \mathrm{M}$ were able to inhibit spontaneous apoptosis that was statistically significant in passage 2. The apoptosis-inhibiting effect of IGF-I on rMF, however, is more convincing after stimulation with $\mathrm{TNF}-\alpha$, which is known to induce apoptosis in rMF (Figure 1).

Effects of IGF-I on Expression of IGF-I Receptor, the CD95 (APO-1; fas)/CD95L System, bcl-2, bcl-xL, bax, p53, p21 $^{\mathrm{WAF} 1}$, NF $\boldsymbol{N B}^{\mathrm{p} 65}$, I $k \mathrm{~B}$, pERK1/2

The results of the Western blot analysis of the proteins derived from the cultures are shown in Figure 2. IGF-I receptor expression is downregulated during activation of HSC and expression on rMF is higher than on activated HSC. No regulation could be observed after IGF-1 stimulation. CD95 receptor expression is upregulated in HSC from day 2 to day 7 and detectable in even higher amounts in rMF as previously shown. ${ }^{19}$ CD95L was not detectable in quiescent HSC (day 2) and rMF but in activated HSC cultures. However, no regulatory effect of IGF-I on this apoptosis regulating system could be observed. Bcl-2 and bax were upregulated in HSC control cultures during 'activation', whereas bcl- $\mathrm{x}_{\mathrm{L}}$ was downregulated. In the rMF cultures (primary culture and passage 2), similar amounts of bcl-2, bax and bcl- $\mathrm{x}_{\mathrm{L}}$ as in activated HSC could be detected. However, IGF-I administration led to a decreased bcl-2- and bcl- $\mathrm{x}_{\mathrm{L}}$-expression as well as to an increase of bax gene expression in HSC (day 2 and day 7). In rMF cultures IGF-I exerted a different effect. Bax expression was not affected, whereas both bcl-2 and bcl- $\mathrm{x}_{\mathrm{L}}$ were upregulated. P53 and $\mathrm{p} 21^{\mathrm{WAF} 1}$, both important for apoptosis regulation in HSC, ${ }^{30}$ are also

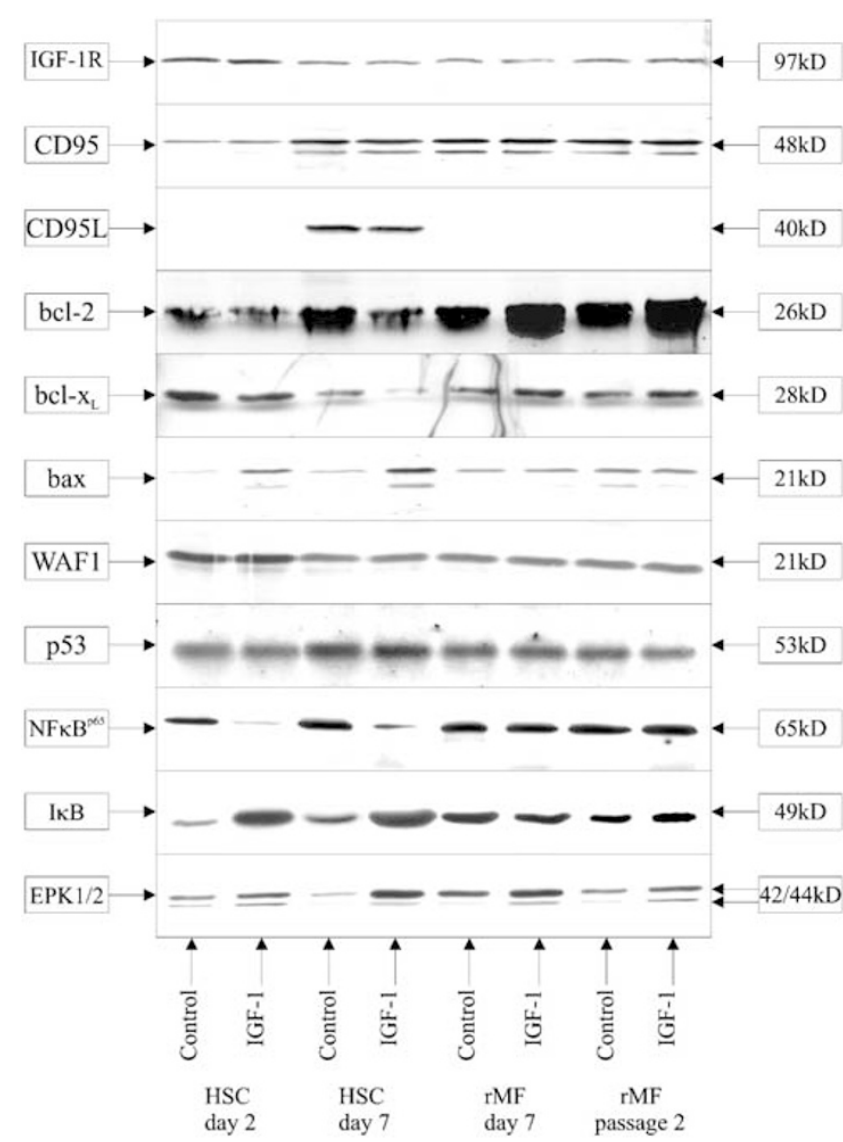

Figure 2 Western blot analysis of IGF-I R, CD95, CD95L, bcl-2, bcl- $x_{\mathrm{L}}$, bax, p21 $1^{\mathrm{WAF} 1}, \mathrm{p} 53, \mathrm{NF} \kappa \mathrm{B}^{\mathrm{p} 65}, \mathrm{I} \kappa \mathrm{B}$ and pERK1/2. SDS-PAGE ( $9 \%$ polyacrylamide) of HSC cell lysates at day 2 and day 7 of culture and rMF (primary culture day 7 and passage 2) (30 $\mu \mathrm{g}$ protein/lane). Controls and cultures treated with IGF-I $\left(10^{-7} \mathrm{M}\right)$ are given. Blots presented show IGF-I R, CD95, CD95L, bcl-2, bcl- $\mathrm{x}_{\mathrm{L}}$, bax, p21 ${ }^{\mathrm{WAF} 1}, \mathrm{p} 53, \mathrm{NF} \kappa \mathrm{B}^{\mathrm{p} 65}, \mathrm{I} \kappa \mathrm{B}$ expression $20 \mathrm{~h}$ after IGF-I administration. Maximum pERK1/2 was detected 30 min after administration of IGF-I (presented). The blots presented are one of three Western blot analysis of three different isolations.

not regulated by IGF-I in rMF. Whereas similar amounts of p21 $1^{\text {WAF1 }}$ were found in 'activated' HSC and rMF, p53 expression is higher in 'activated' HSC. Both $\mathrm{NF}_{\kappa} \mathrm{B}^{\mathrm{p} 65}$ and $\mathrm{I} \kappa \mathrm{B}$ were upregulated in HSC during 'activation'. Whereas $\mathrm{NF} \kappa \mathrm{B}$ was downregulated and $\mathrm{I} \kappa \mathrm{B}$ upregulated in HSC (day 2 and day 7) by IGF-I, their expression remained unaffected in IGF-I-treated rMF (Figure 2). This effect of IGF-I in HSC could also been shown on $\mathrm{NF} \kappa \mathrm{B}$ activity by EMSA. However, a slight but not significant alteration of $\mathrm{NF} \kappa \mathrm{B}$ - activity due to IGF-I could also be observed in rMF (Figure 3). Phosphorylation of ERK1/2 was upregulated maximum in both HSC (day 2 and day 7) and rMF (primary culture and passage 2) by IGF-I $30 \mathrm{~min}$ after administration; however, basis activity was higher in rMF when compared to activated HSC (Figure 5). Afterwards, levels decreased in both cell types reaching control levels $90 \mathrm{~min}$ after IGF-I administration (data not shown). 


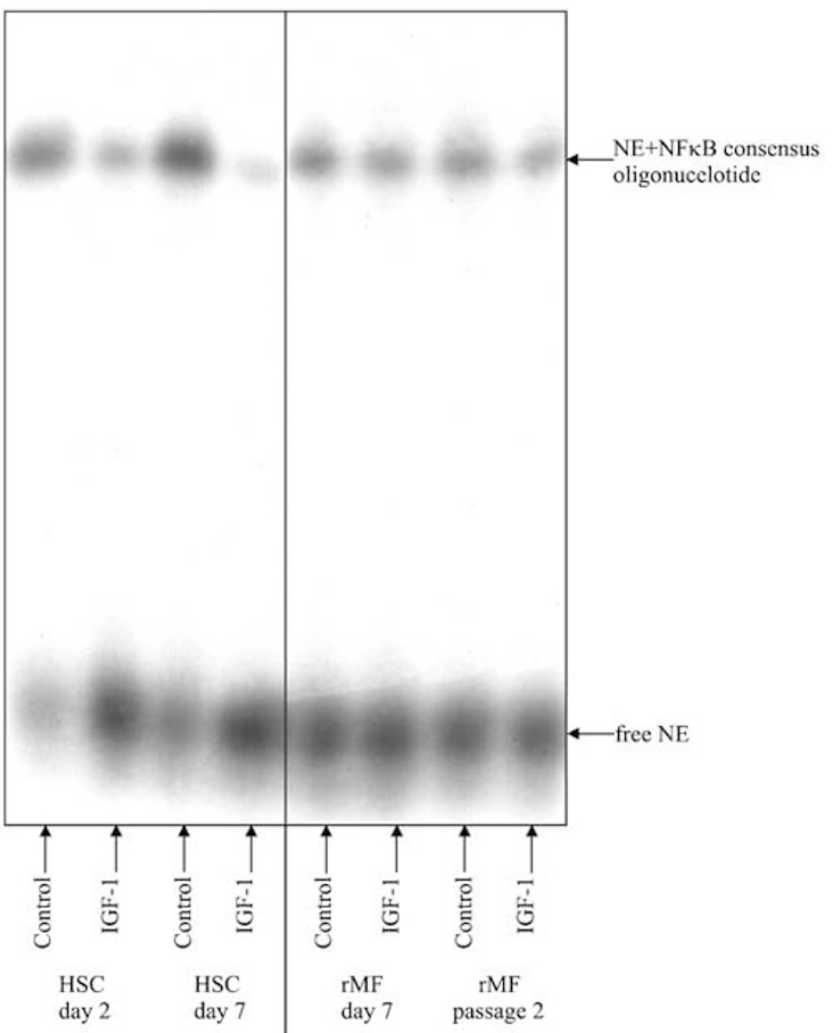

Figure 3 Electrophoretic mobility shift assay to assess NF- $\kappa$ B DNA binding activity. DNA binding activity of nuclear extracts of HSC day 2 and day 7 and rMF (primary culture and passage 2) was assessed using an NF- $\kappa \mathrm{B}$ binding site as probe. Controls $(0.3 \%$ FCS $)$ and cultures incubated with $10^{-7} \mathrm{M}$ IGF-I are presented.

Influence of IGF-I Receptor Phosphorylation Blockage and ERK1/2 Activity on Cell Cycle and Apoptosis of HSC

In the last few years, tyrphostins have been synthesized specifically to block the function of tyrosine kinases. Among these, tyrphostin AG1024 showed significantly lower half-maximal inhibitory concentration 50IC for IGF-I than for insulin receptor. ${ }^{31}$ In addition, we used tyrphostin AG99 to examine the effect of blocking ERK1/2, which is located downstream in the IGF-I signal transduction pathway. As tyrphostin AG99 is known to exert biological activities not only on ERK1 and ERK2 activity but also on EGF-R phosphorylation, ${ }^{32}$ and although tyrphostin A1 (which we used as control), widely described to have no biological activity (only one recent study showed an influence on proliferative activity), ${ }^{33}$ we additionally used U0126 and antisense technique to evaluate the effect of blocking ERK1/2 translation on apoptosis of HSC and $\mathrm{rMF}$.

Whereas administration of tyrphostin A1 had no effect on apoptosis in HSC as well as in rMF, tyrphostin AG1024 slightly inhibited apoptosis in 'activated' HSC. However, in quiescent HSC, acti- vated HSC as well as in rMF cultures tyrphostin AG1024 completely abolished the effect of IGF-I administration on apoptosis to the respective control level (Figure 4a). Tyrphostin AG99 (Figure 4b), U0126 (Figure 4c) and ERK1/2 antisense (Figure 4d) showed different effects on IGF-I-stimulated HSC and rMF cultures. Blocking ERK1/2 by antisense technique and even more by tyrphostin AG99 and U0126 significantly reduced the apoptosis-inducing effect of IGF-I on quiescent as well as in 'activated' HSC but did not abolish it completely, suggesting that apoptosis-stimulating effect is at least in part regulated upstream in the IGF-I signal transduction pathway. On the other hand, in rMF (primary culture as well as in passage 2) ERK1/2 antisense, tyrphostin AG99 and U0126 had no effect on the apoptosis inhibiting effect of IGF-I on these cells. When regarding cell cycle, both ERK1/2 antisense as well as tyrphostin AG99 and U0126 completely abolished the effect of IGF-I on rMF and 'activated' HSC. However, in quiescent HSC (day 2) they reduced S-phase to control levels but a portion of $\mathrm{G}_{2}$-phase cells remained significantly higher than in cultures without IGF-I administration $(50.3 \pm 4.3 \%$; $P<0.05)$.

Effects of ERK1/2 Antisense on Expression of bcl-2, bcl-xL, bax, NF $\kappa^{\mathrm{p}^{65}}$, I $\kappa \mathrm{B}$ in IGF-I-treated HSC and rMF

Inhibiting ERK1/2 translation canceled the upregulation of bax and the downregulation of bcl-2 by IGF-I in HSC (quiescent and 'activated'). However, no effect on $\mathrm{NF} \kappa \mathrm{B}$ or $\mathrm{I} \kappa \mathrm{B}$ expression and activity as well as on bcl- $\mathrm{x}_{\mathrm{L}}$ could be observed. As previously shown bcl- $\mathrm{x}_{\mathrm{L}}$ gene expression is modulated by $\mathrm{NF} \kappa \mathrm{B}^{30}{ }^{30}$ Therefore, the proapoptotic effect of IGF-I on HSC seems to be mediated by ERK1/2 as well as by the $\mathrm{NF} \kappa \mathrm{B}$ system. The latter is modulated upstream of ERK1/2 in the IGF-I signal transduction pathway. As suggested by the apoptosis data in rMF (primary culture and passage 2), ERK1/2 antisense had no effect on $\mathrm{NF} \kappa \mathrm{B}$, IkB, bcl-2, bcl-xL or bax expression (Figure 5).

\section{Effects of ERK1/2 Antisense on Activity of Caspase-8, Caspase-3 and Caspase-9}

ERK1/2 antisense had no effect on caspase-8 activity in HSC or rMF neither in controls nor in IGF-Itreated cell cultures. However, in activated HSC (day 7) and in TNF- $\alpha$-treated rMF, caspase-8 activity was significantly increased (Figure 6a). A highly significant increase of caspase-9 activity could be observed in IGF-I-treated HSC cultures. This increment could be reduced but not totally leveled using ERK1/2 antisense. In rMF TNF- $\alpha$ induced caspase-9 activation. This effect could not be observed in IGF-I-treated cultures and ERK1/2 antisense could not inhibit this effect (Figure 6b). The effects observed for caspase- 9 were even more 


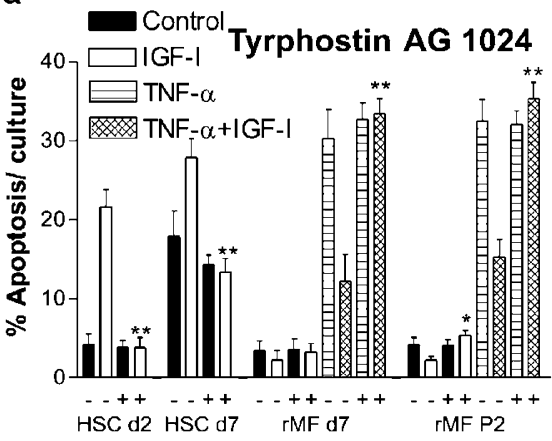

c

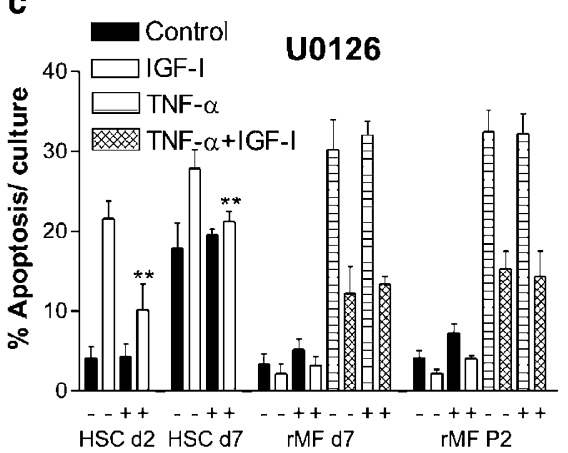

b

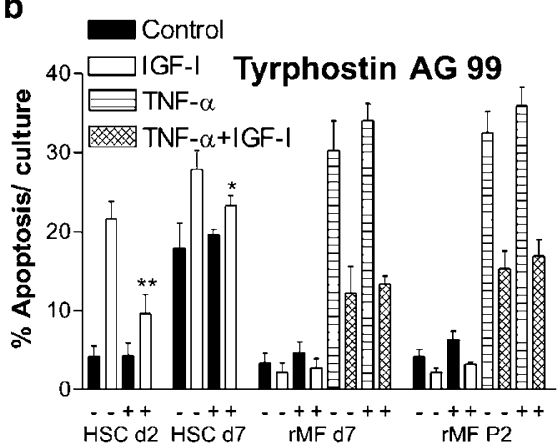

d

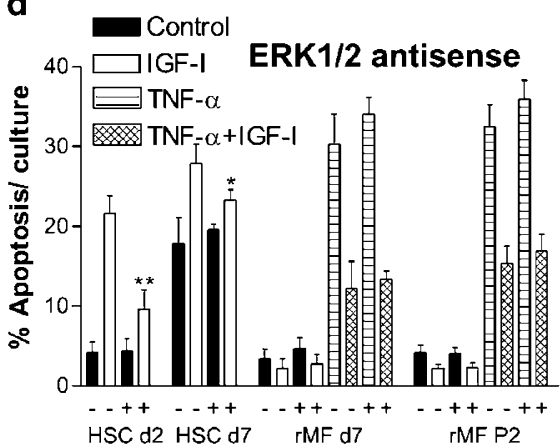

Figure 4 Influence of IGF-I R and ERK1/2 receptor blockage on apoptosis of HSC (day 7) and rMF. Cultures (HSC day 2 and day 7; rMF day 7, passage 2) treated with tyrphostin A1 (negative control) as well as (a) tyrphostin AG1024 (100 $\mu \mathrm{M})$ or (b) tyrphostin AG99 (50 $\mu \mathrm{M}$ ). (c) Effect of U0126 $(100 \mu \mathrm{M})$ or (d) ERK1/2 antisense with and without IGF-I (10 $\left.{ }^{-7} \mathrm{M}\right)$. Also note that tyrphostin A1 or control oligonucleotide had no effect on apoptosis when compared to untreated controls. Apoptosis was detected using the Annexin V/ propidiumiodide method. Values presented are means \pm s.d. of five different isolations. Level of significance: ${ }^{*} P<0.05$; ${ }^{*} P<0.01$ indicating statistical significance of the tyrphostin AG1024; tyrphostin AG99, U0126 or ERK antisense (w/o IGF-I) treated data to their respective control value w/o IGF-I.

emphasized for caspase-3 with respect to the procentage changes of activity (Figure 6c).

Is the Proapoptotic Effect of IGF-1 on HSC Mediated by Its Influence on Cell Cycle?

To answer this question, we performed a timedependent observation of apoptosis using the mitochondrial membrane sensor kit. First, detection of a significant increment of apoptosis after administration of IGF-I could be observed after $4 \mathrm{~h}$ in quiescent HSC (day 2) and after $8 \mathrm{~h}$ in 'activated' HSC (day7) (Figure 7a/c). Using another approach by double-staining of BrdU and TUNEL two additional observations could be stated. First, a significant increase of TUNEL positivity could be observed in quiescent HSC (day 2) and activated HSC (day 7) as early as $2 \mathrm{~h}$ after apoptosis detection using the mitochondrial membrane sensor kit, further suggesting the mitochondrial pathway as the origin of apoptosis in HSC after IGF-I administration. Second, a significant increased BrdU uptake could be observed as early as $2 \mathrm{~h}$ later demonstrating an effect of IGF-I on cell cycle progression, which is about $4 \mathrm{~h}$ after first apoptotic signs could be observed in quiescent as well as activated HSC (Figure 7b). These data reveal that at least in case of IGF-I, induction of the apoptosis process precedes the effect on cell cycle. In contrast, IGF-I administration to myofibroblasts leads to cell cycle progression as measured by BrdU incorporation resulting in an increased cell density. However, it is also remarkable that BrdU uptake of HSC after detection of apoptosis might not only be due to DNA repair mechanisms as in 64\% TUNEL, and BrdU positivity could be observed in cells showing nucleus division.

\section{Discussion}

The present study revealed that IGF-I has different effects on cell cycle and/or proliferation as well as apoptosis and apoptosis signaling, in isolated rat HSC and rMF. IGF-I induces initiation of cell cycle progression in both HSC and rMF but this leads to proliferation only in rMF. Whereas IGF-I induces apoptosis in quiescent and activated HSC an apoptosis-inhibiting effect could be shown in rMF.

As postulated by others and us, IGF-I is so far thought to stimulate the proliferation of HSC. ${ }^{34-41}$ In most cases, however, enhanced DNA synthesis as measured by BrdU or ${ }^{3} \mathrm{H}$-thymidine incorporation was taken to postulate the mitogenic effect of IGF-I. On the contrary, our data show that IGF-I 
1044

a



b



Figure 5 Western blot analysis of bcl-2, bcl- $\mathrm{x}_{\mathrm{L}}$, bax, $\mathrm{NF} \kappa \mathrm{B}, \mathrm{I} \kappa \mathrm{B}$. SDS-PAGE ( $9 \%$ polyacrylamide) of HSC (a) cell lysates at day 2 and day 7 of culture and rMF (b) (primary culture day 7 and passage 2) (30 $\mu$ g protein/lane). Controls (cultures treated with the control oligonucleotide) and cultures treated with IGF-I $\left(10^{-7} \mathrm{M}\right)$ w/o ERK1/2 antisense are given. The blots presented are one of three Western blot analysis of three different isolations.

indeed initiates progression of cell cycle (BrdUELISA as well as elevated S-phase portion) but instead of cell division apoptosis occurs. Furthermore, DNA synthesis seems to continue to occur even after the apoptosis process has been started. Cell counting in fact demonstrated a decrease of cell number most probably due to increased apoptosis. As the greatest part of the HSC cultures after IGF-I administration was found to be in the $\mathrm{G}_{2}$-phase of cell cycle, a $\mathrm{G}_{2}$-arrest may be postulated. In $\mathrm{rMF}$ also an increment of the
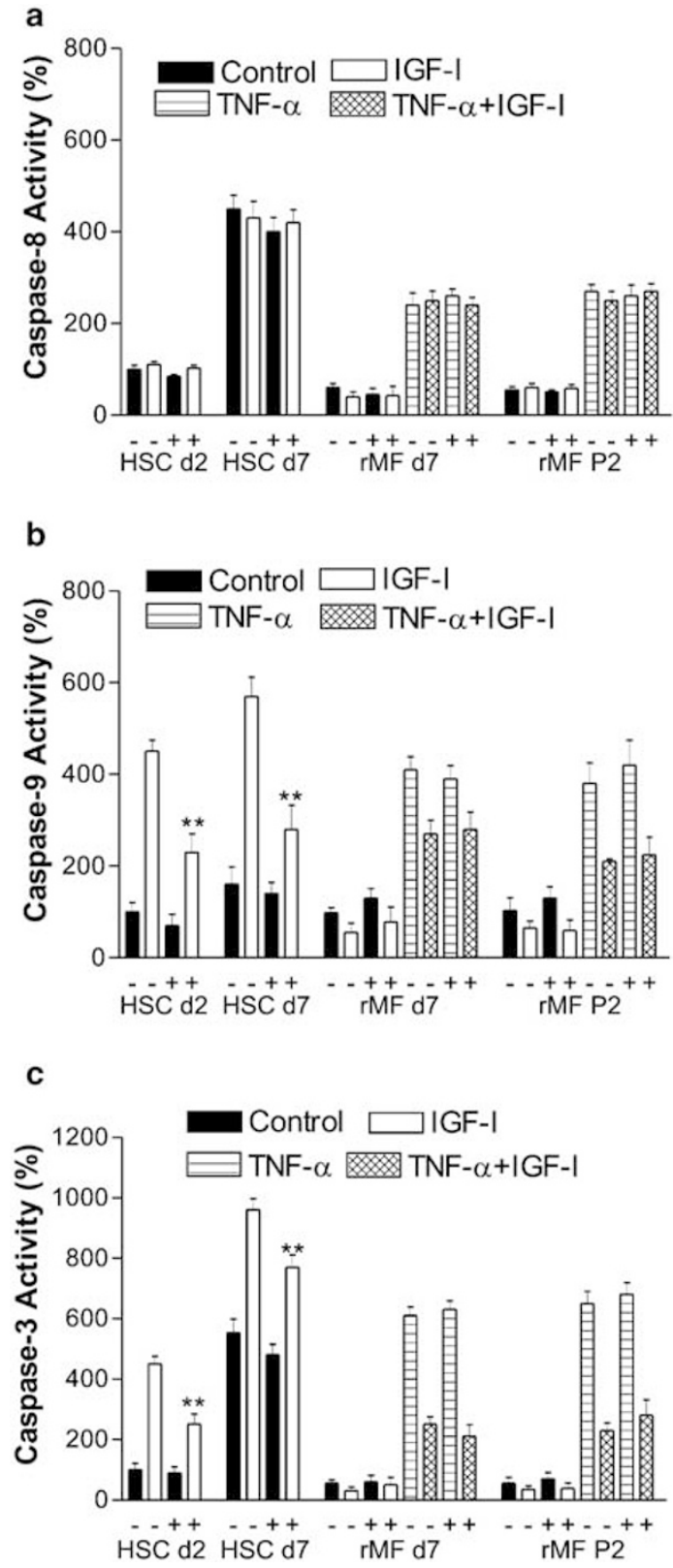

Figure 6 Effects ERK1/2 antisense on activity of caspase-8 (a), caspase-9 (b) and caspase-3 (c). Percentage changes of caspase-8, caspase- 3 and caspase 9 activity $/ 4 \times 10^{6}$ cells during $20 \mathrm{~h}$ incubation with serum-reduced medium ( $0.3 \%$ FCS). Values for quiescent HSC controls were set as $100 \%$. The values for cultures under the influence of IGF-I w/o ERK1/2 antisense relate to the value of the control HSC cultures (day 2). Influence of control oligonucleotide on caspase activity has previously been shown to have no effect on caspase-8, caspase-3 or caspase-9 (data not shown). Values presented are means \pm s.d. of six different isolations. ${ }^{*} P<0.05 ;{ }^{*} P<0.01$ indicating statistical significance of ERK antisense (w/o IGF-I) treated data to their respective control value w/o IGF-I. Level of significance: ${ }^{*} P<0.05$; ${ }^{* *} P<0.01$

S-phase cells after IGF-I administration could be observed, which is comparable to that in activated HSC but no $\mathrm{G}_{2}$-arrest occurred and cell number consecutively increased. These data indicate that although IGF-I initiates progression of cell cycle in 
a

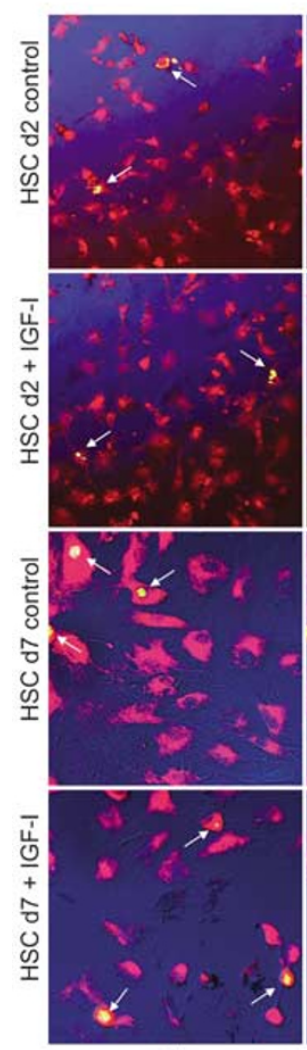

$\mathrm{Oh}$


$4 \mathrm{~h}$

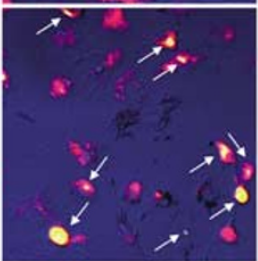

$8 \mathrm{~h}$

c

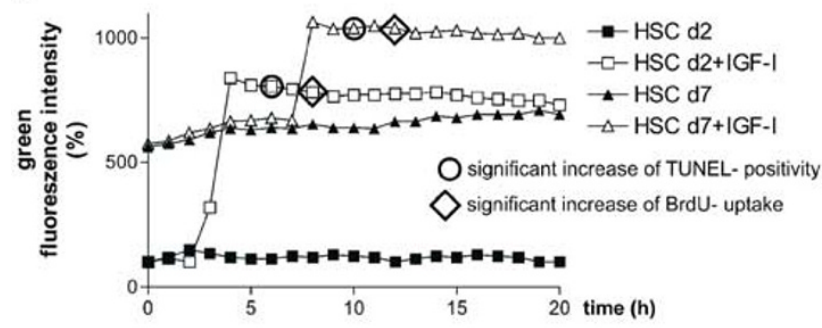

b
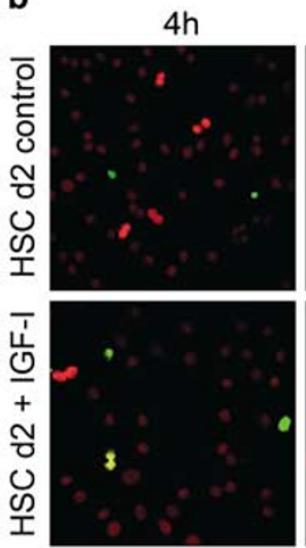

$8 h$


$6 \mathrm{~h}$


$10 \mathrm{~h}$
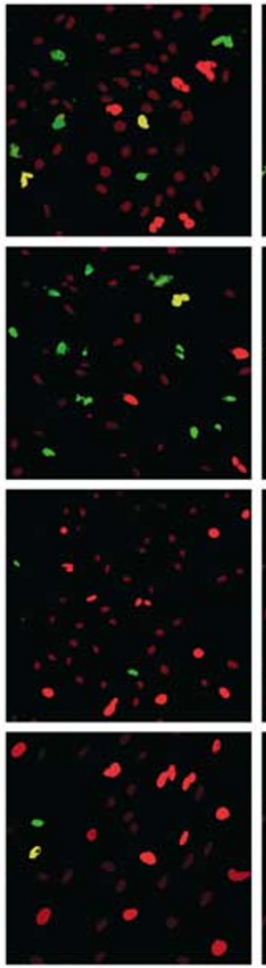

8h
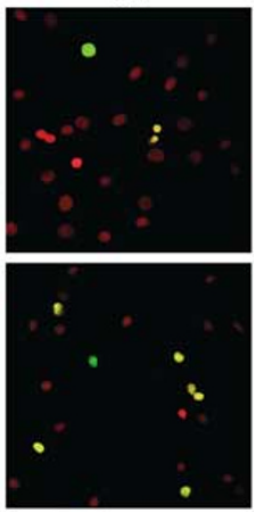

$12 \mathrm{~h}$
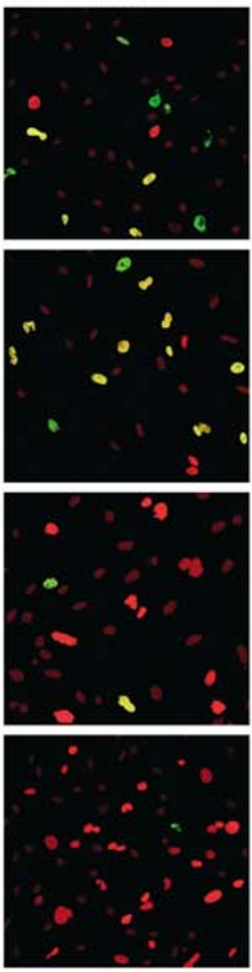

Figure 7 (a) Apoptosis of HSC day 2, day 7. Apoptosis detection by the mitochondrial membrane sensor kit. In healthy cells, the dye accumulates in the mitochondria and fluoresces red. In case of apoptosis, the dye accumulates in the cytoplasm and fluoresces green. Confocal colocalization of red and green presents a yellow color. Apoptotic cells are indicated by arrows. (b) BrdU and TUNEL double staining of HSC and rMF with and without IGF-I. The bright red-stained nuclei represent cells with BrdU uptake (DNA synthesis). TUNEL positivity is shown by green color. Cells that are positive for BrdU uptake and TUNEL appear yellow. The staining was performed 4, 5, 6, 7, $8 \mathrm{~h}$ after IGF-I administration in quiescent HSC (day 2) and 8, 9, 10, 11 and $12 \mathrm{~h}$ after IGF-I administration in activated HSC and rMF. Micrographs before significant changes in TUNEL positivity or BrdU uptake as estimated by counting of 500 cells are given ( $4 \mathrm{~h}$ after IGF-I administration in quiescent HSC and $8 \mathrm{~h}$ in activated HSC and rMF) and micrographs where significant changes in TUNEL positivity and/or BrdU- uptake could be observed (6 and $8 \mathrm{~h}$ after IGF-I administration in HSC day $2 ; 10$ and $12 \mathrm{~h}$ after IGF-I administration in HSC day 7). Note the decrease of cell number in the HSC cultures and the increase of cell number in rMF cultures due to IGF-I as well as the presence of TUNEL- and/or BrdU-positive cells in the HSC controls. (c) Total green fluorescence (apoptotic cells) of HSC cultures with and without IGF-I (day 2 and day 7) was measured using the mitochondrial membrane sensor kit (see (a)). Relative green fluorescence intensity of HSC at day 2 as set as 100\% and fluorescence intensity of cultures under the influence of IGF-I as well as HSC day 7 controls relate to the respective fluorescence intensity of HSC day 2 controls. Additionally, the time points of significant increase of TUNEL positivity $(\bigcirc)$ and BrdU-uptake $(\diamond)$ after IGF-I administration as assessed by the TUNEL/BrdU stainings are indicated.

both HSC and rMF this leads to proliferation only in $\mathrm{rMF}$.

Studies performed so far dealing with the effect of IGF-I on apoptosis in HSC demonstrated contrasting results. An antiapoptotic effect of IGF-I was postulated in vivo and in vitro by Issa et al. ${ }^{42}$ However, as SMA was taken as a marker for identification and characterization of their cells, by which it is not 
possible to differ activated HSC from $\mathrm{rMF}^{17,19,24}$ there are concerns about the origin of these cells. Another study, however, demonstrated an antifibrotic effect of low doses of IGF-I in the model of $\mathrm{CCl}_{4}$ induced liver fibrosis. ${ }^{43}$ In our hands, IGF-I dose dependently induces apoptosis in quiescent as well as in culture-activated HSC. The effect, however, is more evident in quiescent HSC, which might be due to the decrease of the IGF-I receptor after activation. ${ }^{38,44} \mathrm{rMF}$ (primary culture as well as passage 2) show only low amounts of spontaneous apoptosis in culture. However, IGF-I treatment exerted an antiapoptotic effect, especially after induction of apoptosis by TNF- $\alpha$.

The CD95/CD95L system is the major pathway for spontaneous apoptosis in activated $\mathrm{HSC}^{45,46}$ and the lack of CD95L in rMF may be the main reason why this cell population does not undergo apoptosis in culture. ${ }^{19}$ To investigate the proapoptotic effect of IGF-I on HSC and its antiapoptotic effect on rMF in more detail, we examined its influence on the CD95/ CD95L-system, the p53/p21 ${ }^{\mathrm{WAF} 1}$-system, the NF $\kappa \mathrm{B}$ system as well as the bcl-system shown to be of importance for the regulation of apoptosis in HSC. ${ }^{30}$ No effect of IGF-I on CD95, CD95L, p53 and p21 ${ }^{\text {WAF1 }}$ expression could be observed either in HSC or in rMF. Whereas active $\mathrm{NF} \kappa \mathrm{B}$ was downregulated by IGF-I in HSC, most likely due to upregulation of its inhibitor $\mathrm{I} \kappa \mathrm{B}$, no significant effect on the transcription factor could be demonstrated in rMF. In HSC, the antiapoptotic members of the bcl-family bcl-2 and bcl- $\mathrm{x}_{\mathrm{L}}$ were downregulated by IGF-I, whereas gene expression of the major proapoptotic member of the bcl- family, bax, was upregulated. This regulation is clearly different from the effect on $\mathrm{rMF}$ in which the antiapoptotic factors bcl-2 and bcl- $\mathrm{x}_{\mathrm{L}}$ were upregulated and the expression of bax was left unchanged. These data suggest that the bclsystem has to be considered to act proapoptotic in HSC and antiapoptotic in rMF. However, these hypotheses needed more support.

IGF-I receptor signaling involves the RAS/RAF/ mitogen-activated protein (MAP)-kinase pathway and the PI $3^{\prime}$-kinase pathway. ${ }^{47}$ The signaling pathway, however, by which IGF-I stimulates specific cellular responses varies among the different cell types. $^{48}$ We therefore used tyrphostin AG1024, which has a high specifity to block tyrosine kinase activity of the IGF-I receptor ${ }^{31,49}$ to evaluate whether the IGF-I effect is mediated by the IGF-I receptor. However, an action of IGF-I by the insulin receptor cannot be fully excluded. On the other hand, the effects of IGF-I on cell cycle as well as on apoptosis in HSC and rMF were nearly fully abolished by tyrphostin AG1024. In the next step, we used tyrphostin AG99, U0126 and ERK1/2 antisense to block the signal transduction pathway of IGF-I downstream in the MAP-kinase pathway. ERK1/2 antisense and U0126 was additionally used because tyrphostin AG99 not only blocks ERK1/ERK2 tyrosine kinase activity but also acts upstream in the epidermal growth factor (EGF) signaling pathway. ${ }^{32}$ In fact, the apoptosis-inducing effect of IGF-I was significantly reduced by ERK1/2-antisense and even more by tyrphostin AG99. However, data showed that the proapoptotic effect of IGF-I on HSC could not be completely abolished by these means that already could be suspected from the reduced but not leveled caspase-3 activity. On the other hand, ERK1/ 2 antisense as well as tyrphostin AG99 had no effect on the antiapoptotic effect of IGF-I in rMF. Whereas in activated HSC and rMF ERK1/2 antisense and tyrphostin AG99 cancelled the effect of IGF-I on cell cycle, in quiescent HSC the S-phase portion was reduced to control levels but $\mathrm{G}_{2}$-phase portion remained higher than in the controls.

Studies on dependency of the $\mathrm{NF} \kappa \mathrm{B}$ system on ERK1/2 have given contrasting results in different cell systems. All three possibilities, no regulation, upregulation and downregulation, could be found. ${ }^{50-53}$ In HSC, ERK1/2 antisense did not affect downregulation of $\mathrm{NF} \kappa \mathrm{B}$ nor upregulation of $\mathrm{I} \kappa \mathrm{B}$ by IGF-I, suggesting that both are regulated upstream in the IGF-I pathway. On the other hand, $\mathrm{NF} \kappa \mathrm{B}$ and $\mathrm{I} \kappa \mathrm{B}$ are not regulated at all in rMF by IGF-1, suggesting that this system does not influence the apoptosis and proliferation modulation of this cytokine.

The bcl-2 family proteins are critical regulators of apoptosis regulating mitochondria-mediated apoptosis. $^{54}$ Also, the TNF family receptors cause apoptosis among direct activation of the caspase cascade, by affecting members of the bcl-2 family, which also might be suspected from the increased caspase- 9 activity in rMF after TNF- $\alpha$ treatment. ${ }^{55,56}$ An antiapoptotic effect of IGF-I by modulating the bcl-system has often been described; however, in many cases the literature lacks a description of a possible basis in the signaling pathway. ${ }^{57-61}$ Taking a closer look at the bcl-system, ERK1/2 antisense cancelled the effect of IGF-I on bax and bcl-2. The bcl- $\mathrm{x}_{\mathrm{L}}$ expression, however, was not affected. As we could show recently that bcl- $\mathrm{x}_{\mathrm{L}}$ is regulated by $\mathrm{NF} \kappa \mathrm{B}$ in HSC, ${ }^{30}$ but downregulation of the $\mathrm{NF} \kappa \mathrm{B}$ system is not dependent on ERK1/2 activity, this may be the reason why ERK1/2 antisense was not able to suppress IGF-I-mediated increase of caspase-9 and caspase-3 activity and apoptosis induction to control levels. In rMF ERK1/2, did not affect levels of bcl-2, bax and bcl- $\mathrm{x}_{\mathrm{L}}$ indicating an upstream regulation. Whether these bcl proteins in rMF are under the control of PI $3-\mathrm{K}$, as shown in other cell systems ${ }^{62-64}$ has to be elucidated in further studies.

As the IGF-I-mediated upregulation of apoptosis in quiescent and 'activated' HSC is mainly regulated downstream of ERK1/2, the question arises as to whether induction of cell cycle progression itself is the critical point for undergoing apoptosis. As bcl-2family proteins regulate cell death signaling at the mitochondrial level, ${ }^{65}$ we used a mitochondrial membrane sensor kit to detect apoptosis. In both quiescent and activated HSC, upregulation of apoptosis occurred $4 \mathrm{~h}$ before the effect of IGF-I on cell 
cycle could be observed as measured by increment of S-phase cells and BrdU uptake. Furthermore apoptosis detection by TUNEL, revealing effects on the cell nucleus occurred $2 \mathrm{~h}$ after detection of apoptosis-specific changes in the mitochondria, giving even more support that apoptosis induction in HSC due to IGF-I administration starts at the level of the mitochondria. On the other hand, effects of IGF-I on cell cycle as demonstrated by BrdU uptake begins later ( $8 \mathrm{~h}$ after administration in HSC day 2 and $12 \mathrm{~h}$ after administration in HSC day 7 and rMF). Although it can not fully be excluded that in some TUNEL- and BrdU-positive cells BrdU positivity is due to DNA repair mechanisms, this possibility is rather unlikely since even after induction of the apoptotic effect cells with nuclear divisions are observable, $98 \%$ of which are apoptotic. However, in this context, it has also to be considered that nuclear division in HSC does not lead to mitosis (cell division) but to polyploidy. ${ }^{66}$

This in vitro study underlines that rat liver HSC and rat liver myofibroblasts show many similarities but behave differently. As IGF-I is of great importance during liver fibrogenesis and has opposite effects on HSC and rMF concerning apoptosis, and as HSC and rMF have a similar productive potency with respect to extracellular matrix proteins different roles in liver fibrogenesis might be suggested. As a direct interference in fibrogenesis at the level of IGF-IR could lead to a selection of either rMF or HSC, the blockage or usage of the IGF-I pathway might be a useful tool to study the importance of HSC and rMF in liver fibrogenesis in vivo.

\section{Acknowledgements}

We are indebted to S Georgi and A Herbst for excellent technical assistance. This study was supported by the Deutsche Forschungsgemeinschaft SFB 402 (Sonderforschungs-bereich 402 Molekulare und Zelluläre Hepatogastroenterologie), project C6 and the Kompetenznetz Hepatitis, project 11.2.

\section{References}

1 Gressner AM. Mediators of hepatic fibrogenesis [Review]. Hepatogastroenterology 1996;43:92-103.

2 Mathews LS, Norstedt G, Palmiter RD. Regulation of insulin-like growth factor I gene expression by growth hormone. Proc Natl Acad Sci USA 1986;83:9343-9347.

3 Schwander JC, Hauri C, Zapf J, et al. Synthesis and secretion of insulin-like growth factor and its binding protein by the perfused rat liver: dependence on growth hormone status. Endocrinology 1983;113: 297-305.

4 Scharf JG, Schmitz F, Frystyk J, et al. Insulin-like growth factor-I serum concentrations and patterns of insulin-like growth factor binding proteins in patients with chronic liver disease. J Hepatol 1996;25:689-699.
5 Florini JR, Ewton DZ, Coolican SA. Growth hormone and the insulin-like growth factor system in myogenesis. Endocr Rev 1996;17:481-517.

6 Case RD, Piccione E, Wolf G, et al. SH-PTP2/Syp SH2 domain binding specificity is defined by direct interactions with platelet-derived growth factor beta-receptor, epidermal growth factor receptor, and insulin receptor substrate-1-derived phosphopeptides. J Biol Chem 1994;269:10467-10474.

7 Lee CH, Li W, Nishimura R, et al. Nck associates with the SH2 domain-docking protein IRS-1 in insulinstimulated cells. Proc Natl Acad Sci USA 1993;90: 11713-11717.

8 Blakesley VA, Scrimgeour A, Esposito D, et al. Signaling via the insulin-like growth factor-I receptor: does it differ from insulin receptor signaling? Cytokine Growth Factor Rev 1996;7:153-159.

9 Kuhne MR, Pawson T, Lienhard GE, et al. The insulin receptor substrate 1 associates with the SH2-containing phosphotyrosine phosphatase Syp. J Biol Chem 1993;268:11479-11481.

10 Myers Jr MG, Backer JM, Sun XJ, et al. IRS-1 activates phosphatidylinositol 3'-kinase by associating with src homology 2 domains of p85. Proc Natl Acad Sci USA 1992;89:10350-10354.

11 Coolican SA, Samuel DS, Ewton DZ, et al. The mitogenic and myogenic actions of insulin-like growth factors utilize distinct signaling pathways. J Biol Chem 1997;272:6653-6662.

12 Parrizas M, Saltiel AR, LeRoith D. Insulin-like growth factor 1 inhibits apoptosis using the phosphatidylinositol $3^{\prime}$-kinase and mitogen-activated protein kinase pathways. J Biol Chem 1997;272:154-161.

13 Rosenthal SM, Cheng ZQ. Opposing early and late effects of insulin-like growth factor I on differentiation and the cell cycle regulatory retinoblastoma protein in skeletal myoblasts. Proc Natl Acad Sci USA 1995;92:10307-10311.

14 Pukac L, Huangpu J, Karnovsky MJ. Platelet-derived growth factor-BB, insulin-like growth factor-I, and phorbol ester activate different signaling pathways for stimulation of vascular smooth muscle cell migration. Exp Cell Res 1998;242:548-560.

15 Gentilini A, Marra F, Gentilini P, et al. Phosphatidylinositol-3 kinase and extracellular signal-regulated kinase mediate the chemotactic and mitogenic effects of insulin-like growth factor-I in human hepatic stellate cells. J Hepatol 2000;32:227-234.

16 Anonymous. Hepatic stellate cell nomenclature. Hepatology 1996;23:193.

17 Cassiman D, Roskams T. Beauty is in the eye of the beholder: emerging concepts and pitfalls in hepatic stellate cell research. J Hepatol 2002;37:527.

18 Ramadori G, Saile B. Mesenchymal cells in the liver-one cell type or two? Liver 2002;22:283-294.

19 Saile B, Matthes N, Neubauer K, et al. Rat liver myofibroblasts and hepatic stellate cells differ in CD95-mediated apoptosis and response to TNF-alpha. Am J Physiol Gastrointest Liver Physiol 2002;283: G435-G444.

20 Neubauer K, Knittel T, Aurisch S, et al. Glial fibrillary acidic protein-a cell type specific marker for Ito cells in vivo and in vitro. J Hepatol 1996;24:719-730.

21 Knook DL, Blansjaar N, Sleyster EC. Isolation and characterization of Kupffer and endothelial cells from the rat liver. Exp Cell Res 1977;109: 317-329. 
22 de Leeuw AM, Brouwer A, Barelds RJ, et al. Maintenance cultures of Kupffer cells isolated from rats of various ages: ultrastructure, enzyme cytochemistry, and endocytosis. Hepatology 1983;3:497-506.

23 de Leeuw AM, Barelds RJ, de Zanger R, et al. Primary cultures of endothelial cells of the rat liver: a model for ultrastructural and functional studies. Cell Tissue Res 1982;223:201-215

24 Knittel T, Kobold D, Saile B, et al. Rat liver myofibroblasts and hepatic stellate cells: different cell populations of the fibroblast lineage with fibrogenic potential [see comments]. Gastroenterology 1999;117: 1205-1221.

25 Kobold D, Grundmann A, Piscaglia F, et al. Expression of reelin in hepatic stellate cells and during hepatic tissue repair: a novel marker for the differentiation of HSC from other liver myofibroblasts. J Hepatol 2002;36:607-613.

26 Darzynkiewicz Z, Williamson B, Carswell EA, et al. Cell cycle-specific effects of tumor necrosis factor. Cancer Res 1984;44:83-90.

27 Laemmli UK. Cleavage of structural proteins during the assembly of the head of bacteriophage T4. Nature 1970;227:680-685.

28 Towbin H, Staehelin T, Gordon J. Electrophoretic transfer of proteins from polyacrylamide gels to nitrocellulose sheets: procedure and some applications. Proc Natl Acad Sci USA 1979;76:4350-4354.

29 Dignam JD, Lebovitz RM, Roeder RG. Accurate transcription initiation by RNA polymerase II in a soluble extract from isolated mammalian nuclei. Nucleic Acids Res 1983;11:1475-1489.

30 Saile B, Matthes N, El Armouche H, et al. The bcl, NF kappa B and p53/p21(WAF1) systems are involved in spontaneous apoptosis and in the anti-apoptotic effect of TGF-beta or TNF-alpha on activated hepatic stellate cells. Eur J Cell Biol 2001;80:554-561.

31 Parrizas M, Gazit A, Levitzki A, et al. Specific inhibition of insulin-like growth factor-1 and insulin receptor tyrosine kinase activity and biological function by tyrphostins. Endocrinology 1997;138:1427-1433.

32 Pai R, Ohta M, Itani RM, et al. Induction of mitogenactivated protein kinase signal transduction pathway during gastric ulcer healing in rats. Gastroenterology 1998;114:706-713.

33 Twaddle GM, Turbov J, Liu N, et al. Tyrosine kinase inhibitors as antiproliferative agents against an estrogen-dependent breast cancer cell line in vitro. J Surg Oncol 1999;70:83-90.

34 Gressner AM, Brenzel A, Vossmeyer T. Hepatocyteconditioned medium potentiates insulin-like growth factor (IGF) 1 and 2 stimulated DNA synthesis of cultured fat storing cells. Liver 1993;13:86-94.

35 Gressner AM, Lahme B, Brenzel A. Molecular dissection of the mitogenic effect of hepatocytes on cultured hepatic stellate cells. Hepatology 1995;22:1507-1518.

36 Pinzani M, Abboud HE, Aron DC. Secretion of insulinlike growth factor-I and binding proteins by rat liver fat-storing cells: regulatory role of platelet-derived growth factor. Endocrinology 1990;127:2343-2349.

37 Gressner AM. Transdifferentiation of hepatic stellate cells (Ito cells) to myofibroblasts: a key event in hepatic fibrogenesis. Kidney Int 1996;54(Suppl): S39-S45.

38 Scharf JG, Knittel T, Dombrowski F, et al. Characterization of the IGF axis components in isolated rat hepatic stellate cells. Hepatology 1998;27:1275-1284.
39 Gentilini A, Feliers D, Pinzani M, et al. Characterization and regulation of insulin-like growth factor binding proteins in human hepatic stellate cells. J Cell Physiol 1998;174:240-250.

40 Svegliati-Baroni G, Ridolfi F, Di Sario A, et al. Insulin and insulin-like growth factor-1 stimulate proliferation and type I collagen accumulation by human hepatic stellate cells: differential effects on signal transduction pathways. Hepatology 1999;29:1743-1751.

41 Gentilini A, Marra F, Gentilini P, et al. Phosphatidylinositol-3 kinase and extracellular signal-regulated kinase mediate the chemotactic and mitogenic effects of insulin-like growth factor-I in human hepatic stellate cells. J Hepatol 2000;32:227-234.

42 Issa R, Williams E, Trim N, et al. Apoptosis of hepatic stellate cells: involvement in resolution of biliary fibrosis and regulation by soluble growth factors. Gut 2001;48:548-557.

43 Muguerza B, Castilla-Cortazar I, Garcia M, et al. Antifibrogenic effect in vivo of low doses of insulinlike growth factor-I in cirrhotic rats. Biochim Biophys Acta 2001;1536:185-195.

44 Brenzel A, Gressner AM. Characterization of insulinlike growth factor (IGF)-I-receptor binding sites during in vitro transformation of rat hepatic stellate cells to myofibroblasts. Eur J Clin Chem Clin Biochem 1996;34:401-409.

45 Saile B, Knittel T, Matthes N, et al. CD95/CD95Lmediated apoptosis of the hepatic stellate cell. A mechanism terminating uncontrolled hepatic stellate cell proliferation during hepatic tissue repair. Am J Pathol 1997;151:1265-1272.

46 Saile B, Eisenbach C, El Armouche H, et al. Antiapoptotic effect of interferon- $\alpha$ on hepatic stellate cells (HSC) - a novel pathway of IFN- $\alpha$ signal transduction via janus kinase 2 (JAK2) and caspase 8. Eur J Cell Biol 2003;82:31-41

47 Gallaher BW, Hille R, Raile K, et al. Apoptosis: live or die-hard work either way! Horm Metab Res 2001;33:511-519.

48 Petley T, Graff K, Jiang W, et al. Variation among cell types in the signaling pathways by which IGF-I stimulates specific cellular responses. Horm Metab Res 1999;31:70-76.

49 Wen B, Deutsch E, Marangoni E, et al. Tyrphostin AG 1024 modulates radiosensitivity in human breast cancer cells. Br J Cancer 2001;85:2017-2021.

50 Birkenkamp KU, Tuyt LM, Lummen C, et al. The p38 MAP kinase inhibitor SB203580 enhances nuclear factor-kappa B transcriptional activity by a nonspecific effect upon the ERK pathway. Br J Pharmacol 2000;131:99-107.

51 Carter AB, Hunninghake GW. A constitutive active MEK $\rightarrow$ ERK pathway negatively regulates NF-kappa B-dependent gene expression by modulating TATAbinding protein phosphorylation. J Biol Chem 2000;275:27858-27864.

52 Miyazaki T, Katagiri H, Kanegae Y, et al. Reciprocal role of ERK and NF-kappaB pathways in survival and activation of osteoclasts. J Cell Biol 2000;148: 333-342.

53 Hoshi S, Goto M, Koyama N, et al. Regulation of vascular smooth muscle cell proliferation by nuclear factor-kappaB and its inhibitor, I-kappaB. J Biol Chem 2000;275:883-889.

54 Yang Y, Yu X. Regulation of apoptosis: the ubiquitous way. FASEB J 2003;17:790-799. 
55 Breitschopf K, Haendeler J, Malchow P, et al. Posttranslational modification of Bcl-2 facilitates its proteasome-dependent degradation: molecular characterization of the involved signaling pathway. Mol Cell Biol 2000;20:1886-1896.

56 Zhao Y, Li S, Childs EE, Kuharsky DK, et al. Activation of pro-death Bcl-2 family proteins and mitochondria apoptosis pathway in tumor necrosis factor-alphainduced liver injury. J Biol Chem 2001;276: 27432-27440.

57 Nakao Y, Otani H, Yamamura T, et al. Insulin-like growth factor 1 prevents neuronal cell death and paraplegia in the rabbit model of spinal cord ischemia. J Thorac Cardiovasc Surg 2001;122:136-143.

58 Chrysis D, Calikoglu AS, Ye P, et al. Insulin-like growth factor-I overexpression attenuates cerebellar apoptosis by altering the expression of Bcl family proteins in a developmentally specific manner. J Neurosci 2001;21:1481-1489.

59 Matsuzaki H, Tamatani M, Mitsuda N, et al. Activation of Akt kinase inhibits apoptosis and changes in Bcl-2 and Bax expression induced by nitric oxide in primary hippocampal neurons. J Neurochem 1999;73: 2037-2046.

60 Shindler KS, Yunker AM, Cahn R, et al. Trophic support promotes survival of bcl-x-deficient telencephalic cells in vitro. Cell Death Differ 1998;5:901-910.

61 Wang L, Ma W, Markovich R, et al. Regulation of cardiomyocyte apoptotic signaling by insulin-like growth factor I. Circ Res 1998;83:516-522.

62 Gleichmann M, Weller M, Schulz JB. Insulin-like growth factor-1-mediated protection from neuronal apoptosis is linked to phosphorylation of the proapoptotic protein BAD but not to inhibition of cytochrome c translocation in rat cerebellar neurons. Neurosci Lett 2000;282:69-72.

63 Minshall C, Arkins S, Dantzer R, et al. Phosphatidylinositol 3'-kinase, but not S6-kinase, is required for insulin-like growth factor-I and IL-4 to maintain expression of Bcl-2 and promote survival of myeloid progenitors. J Immunol 1999;162:4542-4549.

64 Leverrier Y, Thomas J, Mathieu AL, et al. Role of PI3kinase in Bcl-X induction and apoptosis inhibition mediated by IL-3 or IGF-1 in Baf-3 cells. Cell Death Differ 1999;6:290-296.

65 Yamamura T, Otani H, Nakao Y, et al. IGF-I differentially regulates Bcl-xL and Bax and confers myocardial protection in the rat heart. Am J Physiol Heart Circ Physiol 2001;280:H1191-H1200.

66 Dudas J, Saile B, El Armouche H, et al. Endoreplication and polyploidy in primary culture of rat hepatic stellate cells. Cell Tissue Res 2003;313:301-311. 